\title{
Rasmussen syndrome in a tropical environment: a study of six (6) observations
}

\author{
Carlos Othon Guelngar ${ }^{*}$, Touré Mohamed Lamine', Barry Mamadou Ciré², Diakité Mamady ${ }^{3}$, \\ Konaté Mahadi ${ }^{4}$, Djibo Hamani Bachir Abdoul', Sakadi Foksouna ${ }^{5}$, Djibo Hassane Fatimata ${ }^{6}$, Camara Naby ${ }^{1}$, \\ Kassa Dago François ${ }^{1}$, Bah Fatimatou Korka' ', Camara Doussou' ${ }^{1}$, Millimono Victorine' ${ }^{1}$, Condé Salematou', \\ Sakho Aminata7, Diallo Mohamed Tafsir', Barry Souleymane Djigué1, Diallo Mamadou Saliou', \\ Soumah Fodé Mohamed', Sanni Yaya Aminou', Douna Granga Daouya ${ }^{8}$, Rafkat Said Abdallah', \\ Konaté Mamady ${ }^{1}$, Diallo Souleymane Mbara ${ }^{1}$, Cissé Fodé Abass ${ }^{1}$ and Cissé Amara ${ }^{1}$
}

\begin{abstract}
Background: In sub-Saharan Africa, encephalitis of various etiologies is a major public health problem and Rasmussen syndrome is rarely diagnosed due to under-medicalization. The objective of this study is to describe the clinical and neuroradiological forms, especially since this affection is little known in sub-Saharan Africa as evidenced by the scarcity of publications.

Results: A retrospective, descriptive and analytical study of six (6) cases of Rasmussen syndrome, shows that it is an unrecognized disease in Africa. Men were more represented with a frequency of $67 \%$ with a young age. The clinical picture dominated by $100 \%$ seizures, mental deterioration and hemiparesis. The etiology is still questionable, probably autoimmune in our study.

Conclusion: Rasmussen syndrome accounts for 3\% in 219 patients hospitalized for epileptic conditions. This study shows a clinical profile dominated by recurrent epileptic seizures refractory to the drugs Phenobarbital, Valproic Acid and Carbamazepine, the only antiepileptics available in the country. These results are valid for therapeutic and prognostic discussion.
\end{abstract}

Keywords: Rasmussen syndrome, Chronic encephalitis, Epilepsy, Hemiatrophy, SSA

\section{Background}

Rasmussen syndrome, expression of rare chronic encephalitis, or a systematized degenerative autoimmune pathology appearing mainly in children with sometimes a late-onset has been the subject of several publications with variable frequency [1-5]. This variability depends on the strict nature of the biological and histopathological criteria defining its aetiology, which is still uncertain [5].

\footnotetext{
*Correspondence: carl325@yahoo.fr

${ }^{1}$ Department of Neurology, Academic Hospital, University of Conakry,

Conakry, Guinea

Full list of author information is available at the end of the article
}

The existence of neurological complications in the form of continuous or complex partial epilepsy, motor deficit and progressive mental deterioration is now a well-established fact since the initial publications of Rasmussen (1958) [1], of Caraballo et al. [2], Gray et al. [3], by Oguni et al. [4] and recent by Bien et al. [5-8], de Jaillon-Riviere et al. [9], Varadkar et al. [10], and many other series reviewed. The recent introduction of magnetic resonance imaging and cerebral computed tomography, the development of electroencephalography techniques in neurological practice in sub-Saharan Africa has allowed a better approach to the aetiology of epileptic seizures of rare causes, particularly Rasmussen syndrome. 
We report 6 cases of Rasmussen syndrome in Conakry between 2011 and 2020 intending to reassess this pathology from a clinical, paraclinical, and evolutionary perspective.

The interest of this work lies in the fact that these observations are a good illustration of chronic Rasmussen's encephalitis, a condition that is little known in sub-Saharan Africa, as evidenced by the paucity of publications [11].

\section{Methods}

The six patients (four boys and two girls) were observed between January 1st, 2011, and December 31st, 2020, in Neurology and Paediatric Departments, the only centres in the country to care for patients suffering from chronic neurological pathologies as central motor disabilities, epilepsies, degenerative diseases of the nervous system, demyelinating diseases, neuro-infections, and strokes.

The inclusion criteria were based on those decreed according to the consensus conference of June 2004 published by Bien and colleagues. $[4,5]$ based on the following principles: clinical: focal seizures (with or without EPC and neurological deficit). EEG (EEG Nihon, Neurofax, Japan): slow activity in a hemisphere with or without epileptic activity and the unilateral onset of epilepsy.

MRI / CT (CT Scanners 16- Slice Spiral, Toshiba, USA): focal cortical hemiatrophy and at least one of the following: grey or white matter hyper signal in T2 / FLAIR. Hypersignal or atrophy of the head of the ipsilateral caudate nucleus. Clinical EPC or progressive unilateral neurological deficit. MRI (MRI Scanners $1.5 \mathrm{~T}$, SIGNA $^{\mathrm{TM}}$, USA): progressive focal cortical hemitrophy.

Histopathological: encephalitis (predominantly T lymphocytic) with activated microglial cells and reactive astrocytic gliosis.

The diagnosis of Rasmussen syndrome was made on the three criteria of part A, or two of the criteria of part B. All patients underwent neurological and psychiatric examination and, depending on the semiological presentation, otolaryngological (Laryngoscope FNL10RP3, PENTAX, France) explorations with an audiogram (Audiogram AD629b, interacoustic, France) and ophthalmologic (Ophtalmoscope IEC LR6, 3000 HEINE Mini, Germany) examination with fundoscopy and visual acuity.

Were excluded from the study, all cases presenting a classical clinical picture, but not having the means to perform neuroimaging CT-Scan/MRI.

All patients underwent a series of additional tests (Auto Hematology Analyzer 5, BK-6310 Biobase, Germany), including CBC, ESR, fasting blood glucose, 24-h proteinuria, electrolytes and kidney function, calcium phosphate and magnesium level, iron studies, liver function test.
Viral studies were carried out using PCR testing: HSV1/2, VZV, EBV, CMV, and enterovirus.

Analysis of cerebrospinal fluid (CSF) by lumbar puncture performed in all patients allowed cytological and biochemical evaluation (Automate d'immunoanalyse compact Mini VIDAS, BIOMERIEUX, France): CSF protein, CSF glucose and CSF chloride.

Neuroradiological examinations, in particular MRI, were performed in the four patients with $\mathrm{T} 1$ and $\mathrm{T} 2$ sequences in the axial and frontal planes and cerebral computed tomography in two patients.

During hospitalisation, two electroencephalographic tracings were performed by all patients on admission and discharge. The EEG (EEG Nihon, Neurofax, Japan) graph has been classified into three types:

Type I: EEG with the dominance of alpha rhythms of parieto-occipital topography whose amplitude is greater than $40 \mathrm{~V}$ without pathological rhythms. EEG with the dominance of alpha rhythms of small amplitudes up to 25 $\mu$ volts with a tendency to flatten.

Type II: EEG without dominance proper with the existence of irregular alpha rhythms without pathological theta wave of 4 to 6 cycles / second, especially of temporoparietal topography of low amplitude of 30 to 40 isolated or sometimes grouped in the form of paroxysmal bursts.

Type III: EEG with slow activity in a hemisphere with or without epileptic activity and the unilateral onset of epilepsy. EEG with slow-wave interhemispheric asymmetry at the level of a hemisphere. EEG with slowing of alpha rhythms associated with Theta and delta waves with an asymmetric background.

\section{Results}

Analysis of the results of this study focused on biology, electrophysiology, and neuroradiology studies.

Table 1 summarises the central part of the parameters studied. We have collected six epileptic syndromes with the following semiological orientation: three cases of tonic-clonic seizures, one case of simple partial seizures with Bravais-Jacksonian expression and two cases of complex partial seizures with oral and manual automatisms. The ages of the patients ranged from 4 to 17 years, with a median age of 6.7 years. Personal antecedents were sought in 6 patients; in 2 cases, no systematised disease, none was found apart from endemic malaria, in 3 cases an unsystematic respiratory infection and in 2 cases febrile convulsive seizures reported by the family. In 5 patients, the first treatment chain was traditional medicine, explaining the delays in consultations and hospitalisations in our Centre.

Past medical history showed discordance between the onset of the seizure and the first day of seeking medical 
Table 1 Demographic and clinical data studied in the six patients with Rasmussen syndrome

\begin{tabular}{|c|c|c|c|c|}
\hline $\mathrm{N}^{\circ}$ & Age(year) & Sex & Neuropsychiatry syndrome & $\begin{array}{l}\text { Ophthalmologic } \\
\text { Assessment }\end{array}$ \\
\hline 1 & 5 & $\mathrm{~F}$ & $\begin{array}{l}\text { Left tonic-clonic seizures } \\
\text { Hemiparesis }\end{array}$ & $\mathrm{N}$ \\
\hline 2 & 4 & M & $\begin{array}{l}\text { Bravais-jacksonian simple partial seizures } \\
\text { Right hemiparesis }\end{array}$ & $\mathrm{N}$ \\
\hline 3 & 7 & M & $\begin{array}{l}\text { Partial seizures complex oral and manual automatisms } \\
\text { Progressive intellectual deterioration and epilepsy with right hemiparesis }\end{array}$ & $\mathrm{N}$ \\
\hline 4 & 8 & M & $\begin{array}{l}\text { Complex partial seizures } \\
\text { Emotional disturbances, fear and anxiety, sometimes psychomotor agitation. Left hemiparesis }\end{array}$ & $\mathrm{N}$ \\
\hline 5 & 3 & $\mathrm{~F}$ & Left hemiparesis. Generalized tonic-clonic seizures and delay in psychomotor development & $\mathrm{N}$ \\
\hline 6 & 17 & $M$ & $\begin{array}{l}\text { Left hemiparesis. Cephalalgia paroxysms } \\
\text { Frequent pseudo migraine and Tonic seizures } \\
\text { Intellectual deterioration }\end{array}$ & Uveitis \\
\hline
\end{tabular}

*M: Male; F: Female; N: Normal

care, with a delay of 1 to 2 years in 4 cases. They have all consulted a traditional healer in the first place without success.

CSF protein was evaluated in all patients. It was customary in 3 patients, high in 1 patient and between $0.12 \mathrm{~g} / \mathrm{l}$ and $1.90 \mathrm{~g} / \mathrm{l}$ in 2 patients.

The HIV, VZV, CMV, HVS1/2 serologies were negative in all patients (Table 2).

The electric activity was dominated by type III in all our patients with the appearance of diffuse slow waves of the wave tip type but still presenting with hemispherical dominance, expressing asymmetry.

The brain CT scan revealed in 2 cases a range of hypodensity expression of hemiatrophy (Figs. 1, 2). In 2 cases, MRI showed extensive hemiatrophy predominantly in one hemisphere with an abnormal high-intensity T2 hyperintensity probably compatible with atrophy (Figs. 3, 4).

Under anti-epileptic treatment, the evolution was stable in 4 patients with a frequency of 1 to 2 seizures every six months. The other two patients were lost to follow-up, probably referred to traditional medicine. No case of death was observed during the first year of our patients' follow-up.

Wake-up EEG trace with asymmetric baseline activity and with a right lateralized slowing down evoking a Rasmussen syndrome (Fig. 5).

\section{Discussion}

This study reports 6 cases of Rasmussen syndrome diagnosed at the Academic Hospital. These are all suspected "certain" cases diagnosed in the Neurology and Paediatrics Departments and, to our knowledge, constitute the only series documented in the country.

In Guinea, despite the results obtained in the epilepsy study project [12-16], it remains a significant health problem, especially in the etiological aspects, including Rasmussen syndrome has never been mentioned. The same is true for other studies concerning the aetiology of epilepsy in Africa [17-20], in which a few cases have been reported.

Table 2 Biological, EEG, Brain MRI/CT scan data

\begin{tabular}{|c|c|c|c|}
\hline No & Biology & EEG & MRI/CT scan \\
\hline 1 & SV. Neg & Type III: slow activities associated with bursts of slow waves in the Left hemisphere & CT Progressive left cerebral atrophy \\
\hline 2 & SV Neg & Types II EEG with interhemispheric slow wave asymmetry in the left hemispheric & CT left cerebral atrophy \\
\hline 3 & SV Neg & $\begin{array}{l}\text { Types III: Disorganized graph with restructured alpha rhythms and theta bursts in all } \\
\text { leads with asymmetry }\end{array}$ & $\begin{array}{l}\text { MRI: Left hemiatrophy with ventricular dilation, } \\
\text { cortical atrophy and white matter hypersignal }\end{array}$ \\
\hline 4 & SV Neg & Types III: diffuse suffering with emergence of poly-point right unilateral waves & MRI: right hemiatrophy \\
\hline 5 & SV N & $\begin{array}{l}\text { Type II: EEG without theta rhythm dominance appearing in puffs in the right hemi- } \\
\text { sphere }\end{array}$ & MRI: right hemiatrophy with cortical atrophy \\
\hline 6 & SVN & $\begin{array}{l}\text { Left predominantly diffuse slow-wave activities showing left interhemispheric asym- } \\
\text { metry }\end{array}$ & MRI: left hemiatrophy \\
\hline
\end{tabular}

* SV. Neg: negative serologies 


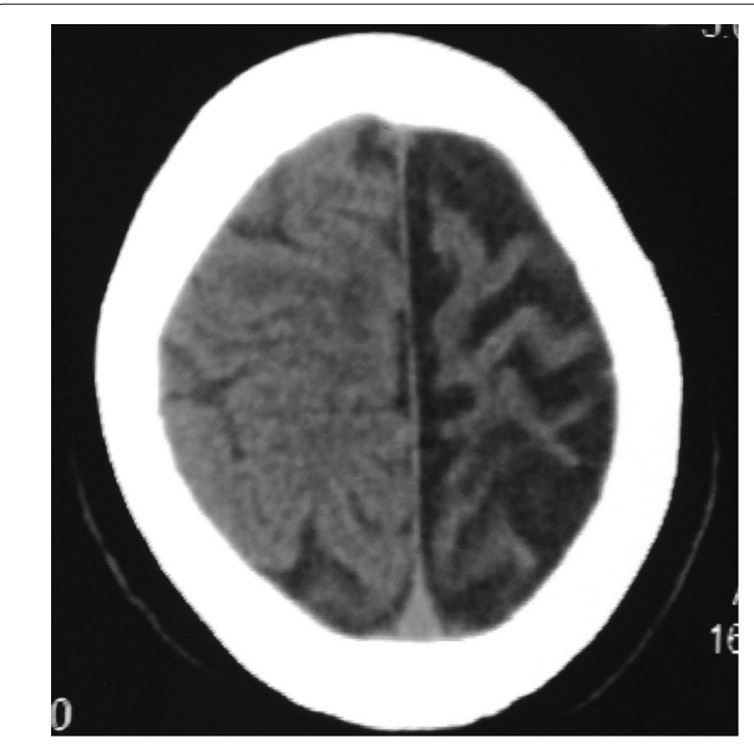

Fig. 1 Brain CT scan showing progressive left cerebral atrophy with hypodensity plaque

These observations confirm the presence and persistence of Rasmussen's encephalitis, a disease that is little known but occurs in populations of all ethnic and geographical origins with an estimated incidence of 2.4 cases per 107 inhabitants [10]. Rasmussen syndrome lacks definitive criteria for its aetiology, and despite the elements of consensus enacted by Bien and colleagues. [5-8], several aspects remain unclear: especially the unilateral lesion of one hemisphere [1] and rarely both [21],

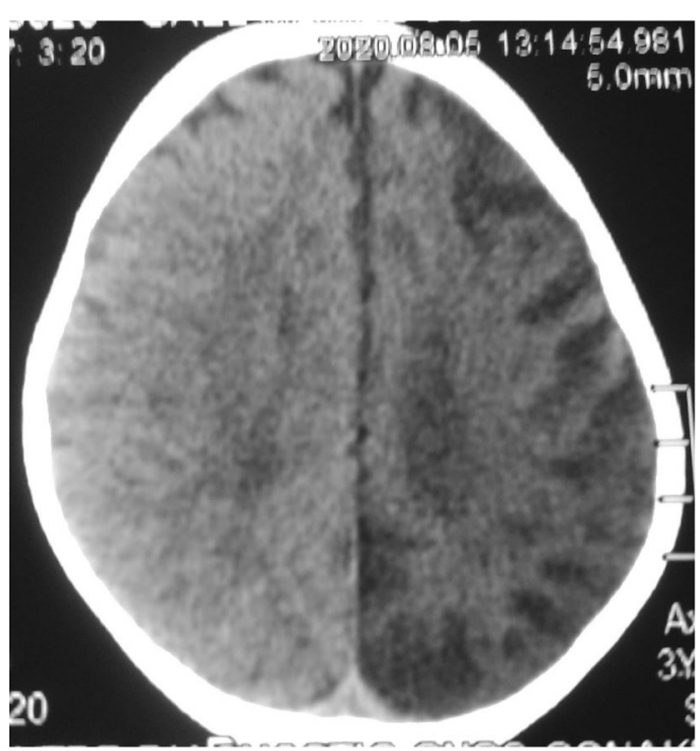

Fig. 2 Brain CT scan: mild left cerebral atrophy

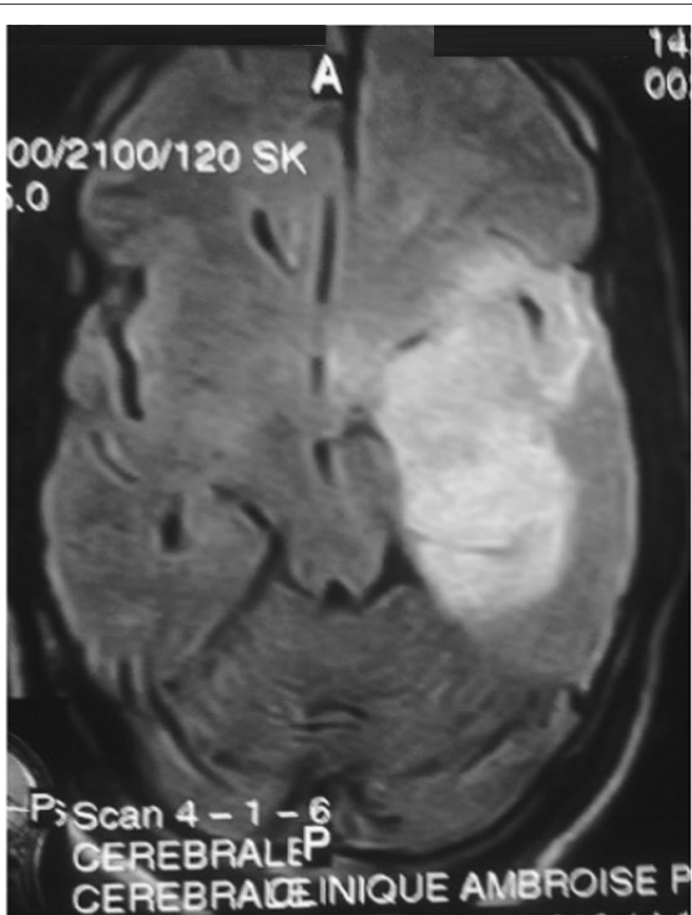

Fig. $3 \mathrm{MRl}$, Extensive lesion in T2 hypersignal, left temporo-parietal cortico-subcortical

the sources of inflammation, the role of cytomegalovirus or herpes [22].

Unknown and underreported condition in sub-Saharan Africa, the incidence of this condition seems low, affecting mainly children from 2 to 15 years old, with a female predominance $(3 / 1)$ and late onset in adults has been reported [3, 17-20].

In our study, the factors associated with its onset were not found because PCR, HSV1 and 2, VZV, EBV, and $\mathrm{CMB}$ were negative, arguing for an autoimmune aetiology $[17,20]$.

In general, the clinical pictures observed in this study do not differ fundamentally from those described in the literature $[1-4,6,8]$ : continuous, complex, and generalised partial seizures resistant to anti-epilepsy, mental deterioration and progressive loss of motor skills. These semiological criteria were found in our patients. The epileptic seizures observed here respond to the known clinical and electrophysiological features of this condition. We will nevertheless note the existence of severe, pseudo-dementia forms and the high frequency of status epilepticus linked to insufficient care and the lack of any neurosurgical approach in a generalised context of an under-medicalised health system [23].

The diagnosis in our study was based mainly on clinical elements, presence of pharmaco-resistant continuous epilepsy, mental weakening depending on the injured 


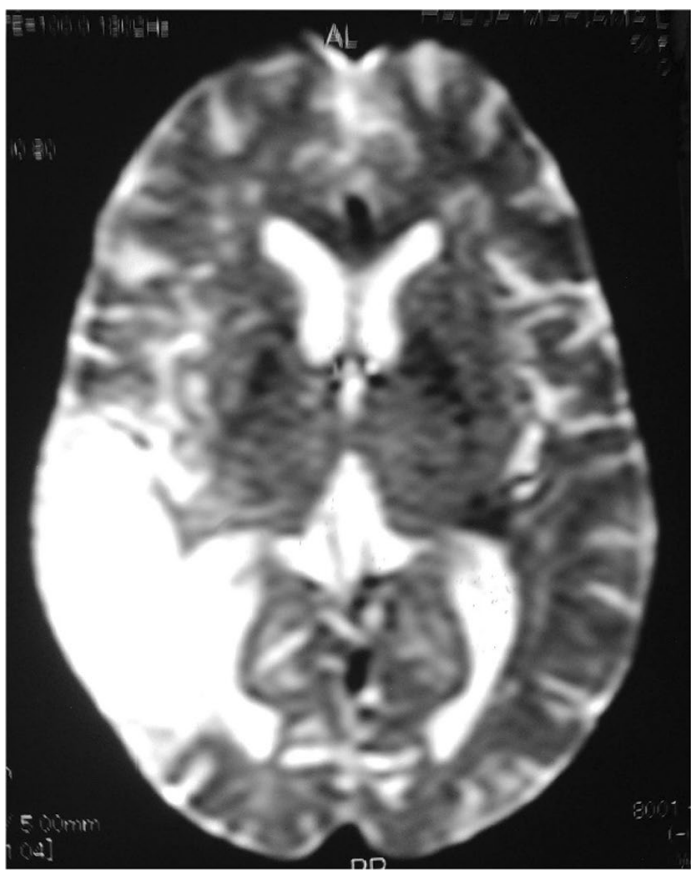

Fig. 4 T2-weighted MRI visualises cortical atrophy with dilation of the furrows in the right hemisphere and hypersignal of the white matter

hemisphere, presence of cerebral hemiatrophy objectified by neuroimaging: T2 FLAIR hyper-signals and volume increase cortical, hyper-signals and cortical atrophy (Fig. 5), cortical atrophy without hyper-signals. These neuroradiological $[5,24,25]$ and clinical criteria are associated with disorders of electroencephalogram activity $[9,10,14]$ of the brain (stage III) in our study with interhemispheric asymmetry. Current data have been found by most of the authors [26-28], some of whom consider that the search for anti-flu-R3 antibodies and the brain biopsy are unhelpful for diagnosis. However, some authors $[5,22]$ believe that the brain biopsy would demonstrate microglial activation: central nervous system macrophages and lymphocytic infiltration.

In our study, the clinical, biological and neuroradiological approach made it possible to exclude neurological syndromes mimicking the Rasmussen picture: Sturge weber disease [29-31], tuberous sclerosis of Bourneville [32-35], Dyke-Davidoff Masson syndrome [36, 37] and Parry-Romberg syndrome [38-41].

The difficulties appear in the forms where Rasmussen's syndrome is associated with these different pathologies as described by HART et al. [23]; in these cases, brain biopsy and resonance imaging may be involved in the differential diagnosis.

On the aetiopathogenesis level, there are no anatomy-physio pathological observations in the literature that allow a unique discussion of the precise etiological hypotheses [7, 10].

Two hypotheses are usually proposed to explain the occurrence of Rasmussen encephalitis: viral by the demonstration of viral inclusions related to cytomegalovirus [42] but absent in other series [43] autoimmune by the demonstration on some biopsy specimens, an immune reaction against $\mathrm{T}$ neurons and astrocytes [44].

Failure to precisely identify the aetiology leads to several treatment regimens: anti-epileptic medication, immunomodulatory treatments with immunoglobulins or plasmapheresis associated with corticosteroid therapy, immunosuppressive therapy $[8,45,46]$ and deafferentation surgery [23].

The unavailability of these different therapeutic regimens in tropical environments requires us to strictly monitor epileptic seizures to avoid fatal illnesses in Africa $[13,15,20]$.

\section{Conclusion}

This retrospective study of 6 cases of Rasmussen syndrome characterized by recurrent epileptic seizures, hemianesthesia, hemiatrophy and mental deterioration should evoke Rasmussen encephalitis, which requires a neuroimaging assessment, MRI/CT brain scan, EEG studies and a biological assessment.

\section{Machines used in the study}

\begin{tabular}{llll}
\hline Machines used & BRAND & $\begin{array}{l}\text { Manufacture } \\
\text { Name }\end{array}$ & $\begin{array}{l}\text { Country of } \\
\text { Origin }\end{array}$ \\
\hline EEG: Head box & Nihon Khoden & Neurofax & Japan \\
Natus neurology & J9T12 & XLICUMONO01 & 2016 USA \\
MRI Scanners & $1.5 T$ & SIGNA & USA \\
CT Scanners & $16-$ Slice Spiral & Toshiba & USA \\
$\begin{array}{l}\text { Auto Hematology } \\
\text { Analyzer 5 }\end{array}$ & BK-6310 & Biobase & Germany \\
$\begin{array}{l}\text { Laryngoscopes: } \\
\text { Ophtalmoscope }\end{array}$ & FNL- 10RP3 & PENTAX & France \\
$\begin{array}{llll}\text { Audiometer } \\
\text { (16966NTE) }\end{array}$ & AD629b & Mo00 HEINE & Germany \\
$\begin{array}{l}\text { Analyser } \\
\text { d'immunoanalyser }\end{array}$ & MTBF & Mini VIDAS & France \\
BIOMERIEUX & & & France \\
\hline
\end{tabular}




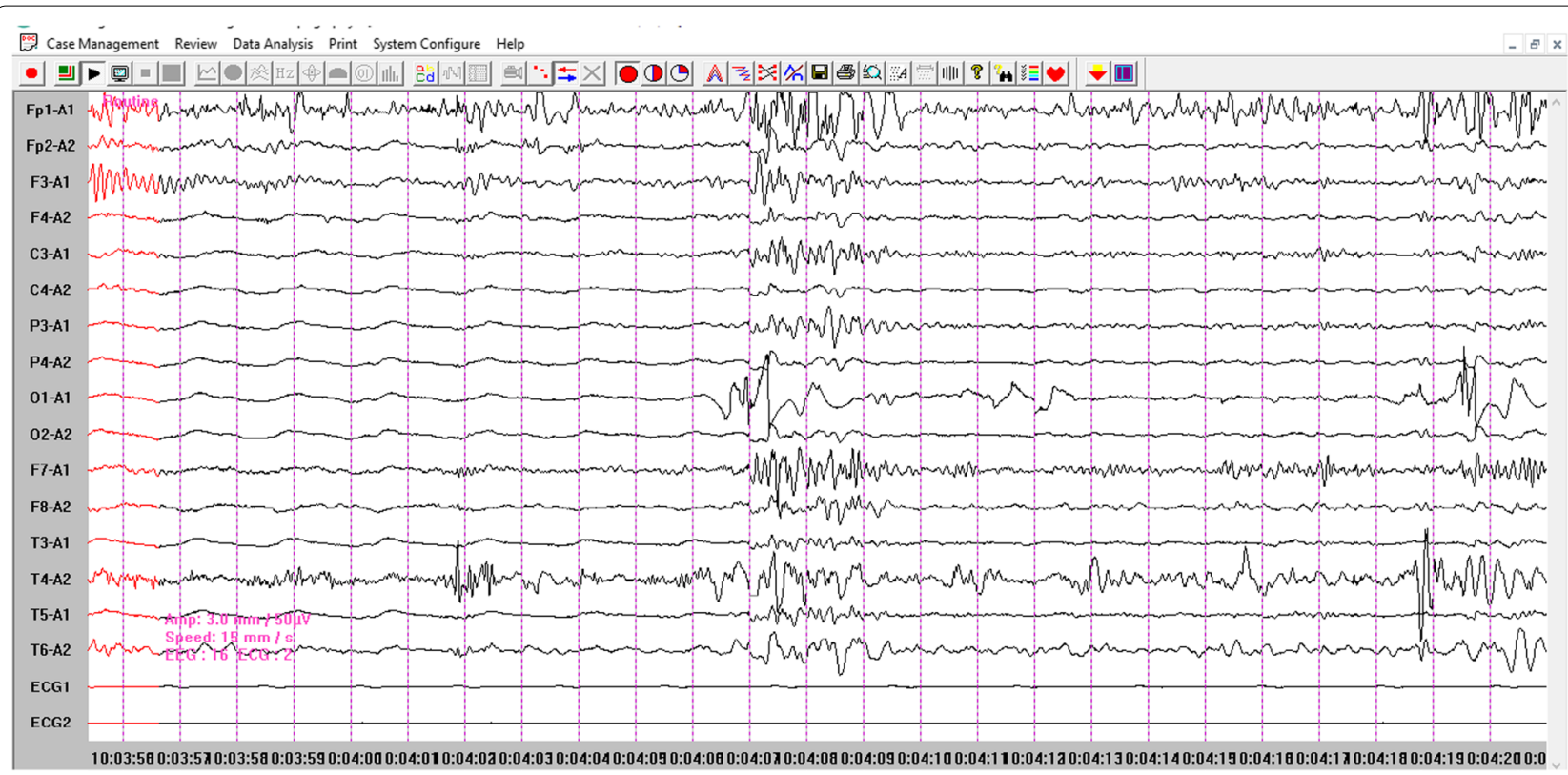

Fig. 5 8-year-old child, seen for progressive intellectual deterioration and epileptic seizures

\section{Abbreviations}

SSA: Sub-Saharan African; MRI: Magnetic resonance imaging; EEG: Electroencephalography; CT: Cranial computed tomography; HIV: Human immunodeficiency virus; VZV: Varicella-zoster virus; CMV: Cytomegalovirus; HSV: Herpes simplex virus; EBV: Epstein-Barr virus.

\section{Acknowledgements}

We thank all the collaborators who help us in this work and more particularly to the Titular Prof CISSE Amara, MD, PhD.

\section{Authors' contributions}

COG: Corresponding author, principal author, Clinical surveillance of hospitalized patients and participation in the drafting. EEG laboratory. TML: EEG laboratory. DHAB; KM: Contribution to bibliographic research, and data entry. BMC: Neuro-pediatric follow-up. D. SM; RSA; KM: Doctors hospitalization and follow-up of the patient 1, 0.2, 3, 4, 5, 6 psychotherapies for parents, KDF: Doctor hospitalization sick 2.6. DGD: Translation of data into English and search for bibliographic references. SA: Contribution of radiological data. BFK; CD; $M V$; CS: Clinical surveillance of hospitalized patients and participation in the writing and discussion of cases. SF; HDF: Interpretation of EEG data. BSD; DMS: Data analysis and external monitoring of patients after discharge from the hospital. SFM; SYA: Reception of patients. Staff and therapeutic control of antiepileptics. CN, DMT: Register of encephalopathies and elements of differential diagnosis. CFA: Deputy head of department, regular patient visits. Ethical aspect. CA: Head of publications coordinator. All authors read and approved the final manuscript.

\section{Funding}

Funding for the diploma framework specializing in Neurology Pr CISSE Amara coordinator.

\section{Availability of data and materials}

The data is available in our service the images and biological data available in our service.

\section{Declarations}

Ethics approval and consent to participate

We obtained informed consent from participants in written form. Ethics Committee of Ignace DEEN CHU chaired by Prof. M Koulibaly Director General of the hospital committee's reference number: ND/99/078/ CNERS /HNID on January 1st, 2011.

\section{Consent for publication}

For the images, we obtained the consent of the parents of the children.

\section{Competing interests}

The authors declare that they no competing interests.

\section{Author details}

${ }^{1}$ Department of Neurology, Academic Hospital, University of Conakry, Conakry, Guinea. ${ }^{2}$ Department of Pediatric, Academic Hospital, University of Conakry, Conakry, Guinea. ${ }^{3}$ Department of Hematology, Academic Hospital, University of Conakry, Conakry, Guinea. ${ }^{4}$ Department of Neurology, National Hospital, Niamey, Niger. ${ }^{5}$ Department of Neurology, National Reference Hospital, NDjamena, Chad. ${ }^{6}$ Department of Neurology, Amirou Boubacar Diallo Hospital, Niamey, Niger. ${ }^{7}$ Department of Radiology, Academic Hospital, University of Conakry, Conakry, Guinea. ${ }^{8}$ Department of Pediatric, Mother and Child Hospital, NDjamena, Chad.

Received: 24 June 2021 Accepted: 3 November 2021

Published online: 24 November 2021

\section{References}

1. Rasmussen T, Olszewski J, Lloydsmith D. Focal seizures due to chronic localized encephalitis. Neurology. 1958;8(6):435-45. https://doi.org/10. 1212/wnl.8.6.435 (PMID: 13566382). 
2. Caraballo R, Tenembaum S, Cersósimo R, Pomata H, Medina C, Soprano $\mathrm{AM}$, et al. Syndrome de Rasmussen [Rasmussen syndrome]. Rev Neurol. 1998;26(154):978-83 (PMID: 9658472).

3. Gray F, Serdaru M, Baron H, Daumas-Duport C, Loron P, Sauron B, et al. Chronic localised encephalitis (Rasmussen's) in an adult with epilepsia partialis continua. J Neurol Neurosurg Psychiatry. 1987;50(6):747-51 https://doi.org/10.1136/jnnp.50.6.747.PMID:3112310;PMCID:PMC10 32082.

4. Oguni $H$, Andermann F, Rasmussen TB. The syndrome of chronic encephalitis and epilepsy. A study based on the MNI series of 48 cases. Adv Neurol. 1992;57:419-33 (PMID: 1543071).

5. Bien CG, Urbach H, Deckert M, Schramm J, Wiestler OD, Lassmann H, et al. Diagnosis and staging of Rasmussen's encephalitis by serial MRI and histopathology. Neurology. 2002;58(2):250-7. https://doi.org/10.1212/ wnl.58.2.250 (PMID: 11805253)

6. Bien CG, Gleissner U, Sassen R, Widman G, Urbach H, Elger CE. An open study of tacrolimus therapy in Rasmussen encephalitis. Neurology. 2004;62(11):2106-9. https://doi.org/10.1212/01.wnl.0000128044.94294.87 (PMID: 15184626).

7. Bien CG, Granata T, Antozzi C, Cross JH, Dulac O, Kurthen M, et al. Pathogenesis, diagnosis and treatment of Rasmussen encephalitis: a European consensus statement. Brain. 2005;128(Pt 3):454-71. https://doi.org/10. 1093/brain/awh415 (Epub 2005 Feb 2 PMID: 15689357).

8. Bien CG, Tiemeier H, Sassen R, Kuczaty S, Urbach H, von Lehe M, et al. Rasmussen encephalitis: incidence and course under randomized therapy with tacrolimus or intravenous immunoglobulins. Epilepsia. 2013;54(3):543-50. https://doi.org/10.1111/epi.12042 (Epub 2012 Dec 6 PMID: 23216622).

9. Jaillon-Riviere V, Dupont S, Bertran F, De La Sayette V, Beuvon F, Baulac M, et al. Le syndrome de Rasmussen à début tardif: caractéristiques cliniques et thérapeutiques [Late onset Rasmussen's syndrome: clinical and therapeutic characteristics]. Rev Neurol (Paris). 2007;163(5):573-80. https://doi. org/10.1016/s0035-3787(07)90463-4 (PMID: 17571025).

10. Varadkar S, Bien CG, Kruse CA, Jensen FE, Bauer J, Pardo CA, et al. Rasmussen's encephalitis: clinical features, pathobiology, and treatment advances. Lancet Neurol. 2014;13(2):195-205. https://doi.org/10.1016/ S1474-4422(13)70260-6.PMID:24457189:PMCID:PMC4005780.

11. Dawodu CO, Akinbo DD. Rasmussen's encephalitis. Niger J Clin Pract. 2013;16(1):113-5. https://doi.org/10.4103/1119-3077.106780 (PMID: 23377484).

12. Williams JA, Cisse FA, Schaekermann M, Sakadi F, Tassiou NR, Hotan GC, et al. Guinea Epilepsy Project. Smartphone EEG and remote online interpretation for children with epilepsy in the Republic of Guinea: Quality, characteristics, and practice implications. Seizure. 2019;71:93-99. doi: https://doi.org/10.1016/j.seizure.2019.05.025.

13. Anand P, Othon GC, Sakadi F, Tassiou NR, Hamani ABD, Bah AK, et al. Guinea epilepsy project epilepsy and traditional healers in the republic of guinea: a mixed methods study. Epilepsy Behav. 2019;92:276-82. https:// doi.org/10.1016/j.yebeh.2019.01.017.

14. Fitts W, Rahamatou NT, Abass CF, Vogel AC, Ghislain AH, Sakadi F, et al. School status and its associations among children with epilepsy in the Republic of Guinea. Epilepsy Behav. 2019;97:275-81. https://doi.org/10. 1016/j.yebeh.2019.05.040

15. Jang M, Sakadi F, Tassiou NR, Abass CF, Grundy SJ, Woga A, et al. Guinea Epilepsy Project Impact of poorly controlled epilepsy in the Republic of Guinea. Seizure. 2018;61:71-7. https://doi.org/10.1016/j.seizure.2018.07 018.

16. Diallo TM, Cisse A, Morel Y, Cisse AF, Souare IS. Premières crises epileptiques tardives. Etude de 42 cas [Late occurrence of first epileptic seizures: a 42-case series]. Med Trop (Mars). 2004;64(2):155-9. PMID: 15460144.

17. Preux PM, Druet-Cabanac M. Epidemiology and aetiology of epilepsy in sub-Saharan Africa. Lancet Neurol. 2005;4(1):21-31. https://doi.org/10. 1016/S1474-4422(04)00963-9 (PMID: 15620854)

18. Prevett M. Epilepsy in sub-Saharan Africa. Pract Neurol. 2013:13(1):14-20. https://doi.org/10.1136/practneurol-2012-000388 (PMID: 23315455).

19. Newton CR, Kariuki SM. Status epilepticus in sub-Saharan Africa: New findings. Epilepsia. 2013;54(Suppl 6):50-3. https://doi.org/10.1111/epi. 12277 (PMID: 24001073)
20. Ba-Diop A, Marin B, Druet-Cabanac M, Ngoungou EB, Newton CR, Preux PM. Epidemiology, causes, and treatment of epilepsy in sub-Saharan Africa. Lancet Neurol. 2014;13(10):1029-44. https://doi.org/10.1016/ S1474-4422(14)70114-0.PMID:25231525;PMCID:PMC5497080.

21. Peariso K, Standridge SM, Hallinan BE, Leach JL, Miles L, Mangano FT, et al. Presentation, diagnosis and treatment of bilateral Rasmussen's encephalitis in a 12-year-old female. Epileptic Disord. 2013;15(3):324-32. https:// doi.org/10.1684/epd.2013.0594 (PMID: 23917753).

22. Maeda Y, Oguni H, Saitou Y, Mutoh A, Imai K, Osawa M, et al. Rasmussen syndrome: multifocal spread of inflammation suggested from MRI and PET findings. Epilepsia. 2003;44(8):1118-21. https://doi.org/10.1046/j. 1528-1157.2003.67602.x (PMID: 12887447).

23. Hart YM, Andermann F, Fish DR, Dubeau F, Robitaille Y, Rasmussen T, et al. Chronic encephalitis and epilepsy in adults and adolescents: a variant of Rasmussen's syndrome? Neurology. 1997;48(2):418-24. https://doi.org/ 10.1212/wnl.48.2.418 (PMID: 9040732)

24. Kim SJ, Park YD, Pillai JJ, Lee MR, Smith JR. A longitudinal MRI study in children with Rasmussen syndrome. Pediatr Neurol. 2002;27(4):282-8. https://doi.org/10.1016/s0887-8994(02)00437-x (PMID: 12435567).

25. Chiapparini L, Granata T, Farina L, Ciceri E, Erbetta A, Ragona F, et al. Diagnostic imaging in 13 cases of Rasmussen's encephalitis: can early MRI suggest the diagnosis? Neuroradiology. 2003;45(3):171-83. https://doi. org/10.1007/s00234-002-0923-7 (Epub 2003 Feb 12 PMID: 12684722).

26. Lamb K, Scott WJ, Mensah A, et al. Prevalence and clinical outcome of Rasmussen encephalitis in children from the United Kingdom. Dev Med Child Neurol. 2013;55(suppl 1):14.

27. HARTY, ANDERMANN F. (2002). Le syndrome de Rasmussen. In:Roger J, Bureau M, Dravet C (eds). Les syndromes epileptiques de l'enfant et de I'adolescent. 3 ed., pp. 495-512, John Libbey.Eastleigh (UK).

28. McLachlan RS, Girvin JP, Blume WT, Reichman H. Rasmussen's chronic encephalitis in adults. Arch Neurol. 1993;50(3):269-74. https://doi.org/10. 1001/archneur.1993.00540030035011 (PMID: 8382920).

29. Antoun H, Adamsbaum C. Quel est votre diagnostic. J Neuroradiol. 2000;28:241-3

30. Boukobza M, Enjolras O, Cambra M, Merland J. Syndrome de Sturge-Weber. Données actuelles de l'imagerie neuroradiologique [Sturge-Weber syndrome. The current neuroradiologic data]. J Radiol. 2000;81 (7):765-71. PMID: 10915989

31. Pfund Z, Kagawa K, Juhász C, Shen C, Lee JS, Chugani DC, et al. Quantitative analysis of gray- and white-matter volumes and glucose metabolism in Sturge-Weber syndrome. J Child Neurol. 2003;18(2):119-26. https://doi. org/10.1177/08830738030180021501 (PMID: 12693779).

32. Crino PB, Nathanson KL, Henske EP. The tuberous sclerosis complex. N Engl J Med. 2006;355(13):1345-56. https://doi.org/10.1056/NEJMra0553 23 (PMID: 17005952).

33. Koh S, Jayakar P, Dunoyer C, Whiting SE, Resnick TJ, Alvarez LA, et al. Epilepsy surgery in children with tuberous sclerosis complex: presurgical evaluation and outcome. Epilepsia. 2000;41(9):1206-13. https://doi.org/ 10.1111/j.1528-1157.2000.tb00327.x (PMID: 10999561).

34. Narayanan V. Tuberous sclerosis complex: genetics to pathogenesis. Pediatr Neurol. 2003;29(5):404-9. https://doi.org/10.1016/j.pediatrneurol. 2003.09.002 (PMID: 14684235).

35. Jansen FE, Braun KP, van Nieuwenhuizen O, Huiskamp G, Vincken KL, van Huffelen AC, et al. Diffusion-weighted magnetic resonance imaging and identification of the epileptogenic tuber in patients with tuberous sclerosis. Arch Neurol. 2003;60(11):1580-4. https://doi.org/10.1001/archn eur.60.11.1580 (PMID: 14623730).

36. Jilowa CS, Meena PS, Rohilla J, Jain M. Dyke-Davidoff-Masson syndrome. Neurol India. 2017;65(2):413-4. https://doi.org/10.4103/neuroindia.NI_ 1004_15 (PMID: 28290419).

37. Nand N, Venu S, Yadav M, Deshmukh AR, Mittal R. Dyke-Davidoff-Masson syndrome. J Assoc Phys India. 2016;64(4):71 (PMID: 27734645)

38. Stone J. Parry-Romberg syndrome. Pract Neurol. 2006. https://doi.org/10. 1136/jnnp.2006.089037.

39. Aydın H, Yologlu Z, Sargın H, Metin MR. Parry-Romberg syndrome. Physical, clinical, and imaging features. Neurosciences (Riyadh). 2015;20(4):368-71. https://doi.org/10.17712/nsj.2015.4.20150142. 
40. Bhoyrul B, Clark S. Parry-Romberg syndrome and morphoea en coup de sabre. Arch Dis Child. 2019;104(4):400. https://doi.org/10.1136/archdischi ld-2018-314900.

41. Bucher F, Fricke J, Neugebauer A, Cursiefen C, Heindl LM. Ophthalmological manifestations of Parry-Romberg syndrome. Surv Ophthalmol. 2016;61(6):693-701. https://doi.org/10.1016/j.survophthal.2016.03.009.

42. Villani F, Pincherle A, Antozzi C, Chiapparini L, Granata T, Michelucci R, et al. Adult-onset Rasmussen's encephalitis: anatomical-electrographicclinical features of 7 Italian cases. Epilepsia. 2006;47(Suppl 5):41-6. https://doi.org/10.1111/j.1528-1167.2006.00876.x (PMID: 17239105).

43. Vadlamudi L, Galton CJ, Jeavons SJ, Tannenberg AE, Boyle RS. Rasmussen's syndrome in a 54 year old female: more support for an adult variant. J Clin Neurosci. 2000;7(2):154-6. https://doi.org/10.1054/jocn.1999.0173 (PMID: 10844806).

44. Schwab N, Bien CG, Waschbisch A, Becker A, Vince GH, Dornmair K, Wiendl H. CD8+ T-cell clones dominate brain infiltrates in Rasmussen encephalitis and persist in the periphery. Brain. 2009;132(Pt 5):1236-46. https://doi.org/10.1093/brain/awp003 (Epub 2009 Jan 29 PMID: 19179379).

45. Granata T, Fusco L, Gobbi G, Freri E, Ragona F, Broggi G, et al. Experience with immunomodulatory treatments in Rasmussen's encephalitis. Neurology. 2003;61(12):1807-10. https://doi.org/10.1212/01.wnl.0000099074. 04539.e0 (PMID: 14694056).

46. Owens GC, Huynh MN, Chang JW, McArthur DL, Hickey MJ, Vinters HV, et al. Differential expression of interferon- $\gamma$ and chemokine genes distinguishes Rasmussen encephalitis from cortical dysplasia and provides evidence for an early Th1 immune response. J Neuroinflammation. 2013;2(10):56. https://doi.org/10.1186/1742-2094-10-56.PMID:23639073; PMCID:PMC3657540.

\section{Publisher's Note}

Springer Nature remains neutral with regard to jurisdictional claims in published maps and institutional affiliations.

\section{Submit your manuscript to a SpringerOpen ${ }^{\circ}$ journal and benefit from:}

- Convenient online submission

- Rigorous peer review

- Open access: articles freely available online

- High visibility within the field

- Retaining the copyright to your article

Submit your next manuscript at $\boldsymbol{\nabla}$ springeropen.com 